\title{
U.S. Supreme Court Amicus Brief of Law Professors in Support of Respondents, J. Mclntyre Machinery Ltd. v. Nicastro, No. 09-1343
}

Adam Steinman

University of Alabama - School of Law, asteinman@law.ua.edu

\section{Recommended Citation}

Adam Steinman, U.S. Supreme Court Amicus Brief of Law Professors in Support of Respondents, J. McIntyre Machinery Ltd. v. Nicastro, No. 09-1343, (2011).

Available at: https://scholarship.law.ua.edu/fac_working_papers/689 
No. 09-1343

\section{$\mathfrak{J n} \mathbb{U} \mathfrak{d h e}$ \\ Gupreme Court of the alnited States}

J. MCINTYRE MACHINERY LTD.,

Petitioner,

v.

ROBERT NICASTRO, et ux.,

Respondents.

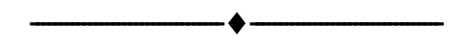

On Writ Of Certiorari To The Supreme Court Of New Jersey

\section{$\longrightarrow \longrightarrow$ \\ BRIEF OF LAW PROFESSORS AS AMICI CURIAE IN SUPPORT OF RESPONDENTS}

$\begin{array}{ll} & \\ \text { ADAM STEINMAN } & \text { JUSTIN T. GREEN } \\ \text { SETON HALL UNIVERSITY } & \text { Counsel of Record } \\ \text { SCHOOL OF LAW } & \text { JAMES P. KREINDLER } \\ \text { One Newark Center } & \text { ANTHONY TARRICONE } \\ \text { Newark, NJ 07102 } & \text { KREINDLER \& KREINDLER LLP } \\ \text { (973) 642-8882 } & \text { 750 Third Avenue } \\ & \text { New York, NY 10017 } \\ & \text { (212) 973-3403 } \\ & \text { JGreen@Kreindler.com } \\ & \text { Attorneys for Amici Curiae }\end{array}$

COCKLE LAW BRIEF PRINTING CO. (800) 225-6964 OR CALL COLLECT (402) 342-2831 


\section{TABLE OF CONTENTS}

$\begin{array}{lr} & \text { Page } \\ \text { TABLE OF CONTENTS ................................. } & \text { i } \\ \text { TABLE OF AUTHORITIES ............................. } & \text { ii } \\ \text { IDENTITY AND INTEREST OF AMICI CURIAE.... } & 1 \\ \text { SUMMARY OF ARGUMENT .......................... } & 1 \\ \text { ARGUMENT ............................................... } & 4\end{array}$

I. A State May Exercise Jurisdiction over a Manufacturer who Makes Efforts to Serve - Directly or Indirectly - the Market in that State and Whose Product Thereby Causes Injury in that State ........................

II. A Manufacturer that Purposefully Endeavors to Serve the U.S. Market as a Whole Necessarily Serves, at Least Indirectly, the Market for Each U.S. State........

III. Allowing Jurisdiction Would Not Conflate "National Contacts" with "State Contacts" ...

IV. Allowing Jurisdiction Will Not Invite "a Subjective Judge-by-Judge Assessment of What is Fair and Just" or Deprive Defendants of "Fair Warning" That Their Conduct Will Subject Them to Jurisdiction ......

V. The New Jersey Supreme Court's Conclusion that Personal Jurisdiction Exists Is Consistent with this Court's Case Law and Should Be Affirmed 
TABLE OF CONTENTS - Continued

\section{Page}

\section{APPENDIX}

List of Amici Professors ......................................1a 
TABLE OF AUTHORITIES

Cases

A. Uberti \& C. v. Leonardo, 892 P.2d 1354 (Ariz. 1995) .29

Anderson v. Creighton, 483 U.S. 635 (1987) .28

Asahi Metal Industry Co. Ltd. v. Superior Court, 480 U.S. 102 (1987) passim

Barone v. Rich Bros. Interstate Display Fireworks Co., 25 F.3d 610 (8th Cir. 1994) .29

Burger King Corp. v. Rudzewicz, 471 U.S. 462 (1985)...

passim

Burnham v. Superior Court, 495 U.S. 604 (1991).... $24,25,26$

Helicopteros Nacionales de Colombia, S.A. v. Hall, 466 U.S. 408 (1984) ...................................10

Hertz Corp. v. Friend, 130 S. Ct. 1181 (2010). .26

Hicks v. Kawasaki Heavy Industries, 452 F. Supp. 130 (M.D. Pa. 1978) 15,16

Insurance Corp. of Ireland, Ltd. v. Compagnie des Bauxites de Guinee, 456 U.S. 694 (1982) 23

International Shoe Co. v. Washington, 326 U.S. 310 (1945) $3,4,5,7,28$

Kernan v. Kurz-Hastings, Inc., 175 F.3d 236 (2d Cir. 1999) 29

Merrell Dow Pharmaceuticals Inc. v. Thompson, 478 U.S. 804 (1986) 
TABLE OF AUTHORITIES - Continued

Page

Omni Capital Intern., Ltd. v. Rudolf Wolff \& Co., 484 U.S. 97 (1987).................................22, 23

Pennoyer v. Neff, 95 U.S. 714 (1877)...................4, 28

Rockwell International Corp. $v$. Costruzioni Aeronautiche Giovanni Agusta, 553 F. Supp. 328 (E.D. Pa. 1982) .....................................14, 15

Tobin v. Astra Pharmaceutical Products, Inc., 993 F.2d 528 (6th Cir. 1993) .29

Vermeulen v. Renault, U.S.A., Inc., 985 F.2d 1534 (11th Cir. 1993). .8

World-Wide Volkswagen Corp. v. Woodson, 444 U.S. 286 (1980). passim

Wright v. American Home Products Corp., 768 A.2d 518 (Del. Super. 2000) .29

RULES

Federal Rule of Civil Procedure 4(k)(2) ........21, 22, 23

OTHER AUTHORITIES

Borchers, Patrick J., The Death of the Constitutional Law of Personal Jurisdiction: From Pennoyer to Burnham and Back Again, 24 U.C. DAVIS L. REV. 19 (1990)..............................24

Fed. R. Civ. P. 4, advisory committee notes (1993 amendment, subdivision (k)) .22 
TABLE OF AUTHORITIES - Continued

Page

Lilly, Graham C., Jurisdiction over Domestic and Alien Defendants, 69 VA. L. REv. 85 (1983)....

Redish, Martin H., Due Process, Federalism, and Personal Jurisdiction: A Theoretical Evaluation, 75 Nw. U. L. REv. 1112 (1981)......24, 27

Spencer, A. Benjamin, Jurisdiction to Adjudicate: A Revised Analysis, 73 U. CHI. L. REv. 617 (2006) 


\section{IDENTITY AND INTEREST OF AMICI CURIAE ${ }^{1}$}

Amici curiae are law professors and legal scholars from across the country with expertise in the areas of civil procedure, conflict of laws, and transnational litigation. Amici have an interest in the proper interpretation of the constitutional restrictions on personal jurisdiction and their effect on civil adjudication. Amici believe that this Court's wellestablished principles confirm that New Jersey courts may permissibly exercise jurisdiction in this case. A list of Amici is set forth in the appendix hereto.

\section{SUMMARY OF ARGUMENT}

This Court's fractured decision in Asahi Metal Industry Co. Ltd. v. Superior Court, 480 U.S. 102 (1987), has spurred some uncertainty about whether U.S. courts may constitutionally exercise jurisdiction over foreign manufacturers whose products are sold to U.S. customers and cause injury in the United States. Although Asahi divided 4-4 on whether the foreign manufacturer in that case had established minimum contacts with California, both sides of the

${ }^{1}$ Letters from counsel for all parties evidencing their consent to the timely filing of amicus curiae briefs have been filed with the Court. Pursuant to Rule 37.6, counsel for amici state that no counsel for a party authored any part of this brief, nor did any person or entity other than amici or counsel make a monetary contribution to its preparation. 
split endorsed this long-standing consensus: a manufacturer establishes minimum contacts with the forum when it purposefully seeks to serve - directly or indirectly - the market in the forum state and its product thereby causes injury in that state. This Court should reaffirm this principle and conclude that New Jersey courts may properly assert jurisdiction over Petitioner, a British manufacturer of large metal shearing machines.

There is no question that Petitioner purposefully sought to serve and profit from the U.S. market for its products by, among other things: directly engaging a U.S.-based company to be the exclusive distributor for Petitioner's machines in the territory of the United States; touting in its literature that its machines comply with American safety standards; and having its own high-level officials attend dozens of U.S. trade shows in an effort to promote the sales of its machines in the United States. By taking these purposeful steps to reach the entire U.S. market, Petitioner necessarily sought to serve, at least indirectly, the particular states that comprise the United States. The shear machine at issue in this case went directly from the Petitioner, to its U.S. distributor, to the New Jersey business where Mr. Nicastro worked and was injured. Given Petitioner's efforts to reach and profit from the U.S. market as a whole, sales to customers in particular U.S. states are hardly the kind of random, fortuitous, or attenuated contacts that cannot be fairly attributed to the Petitioner. 
Contrary to the arguments of Petitioner and its amici, upholding jurisdiction would not permit nationwide jurisdiction based merely on "national contacts" (rather than contacts with the forum state). Nor would upholding jurisdiction invite judges to subjectively assess "what is fair and just" or deprive defendants of "fair warning" that they will be subject to jurisdiction. To refuse jurisdiction on these facts, on the other hand, would embrace a logical impossibility: that a manufacturer can purposefully target the U.S. market generally without also targeting the states that make up the territory of the United States. Moreover, it would immunize such a manufacturer from jurisdiction in any U.S. state, despite its deliberate efforts to access the entire U.S. market. This would create an undesirable and unnecessary disparity between a foreign manufacturer's purposeful conduct directed at the U.S. market and the power of U.S. courts to exercise jurisdiction over claims arising from that conduct.

In fact, the exercise of jurisdiction in this case is entirely consistent with this Court's precedent. Its constitutionality is confirmed by the reasoning of both Justice Brennan's and Justice O'Connor's Asahi opinions, and by basic jurisdictional principles that have never been called into question since International Shoe articulated the minimum-contacts framework 65 years ago. This Court should affirm the decision below. 


\section{ARGUMENT}

\section{A STATE MAY EXERCISE JURISDICTION OVER A MANUFACTURER WHO MAKES EFFORTS TO SERVE - DIRECTLY OR INDIRECTLY - THE MARKET IN THAT STATE AND WHOSE PRODUCT THEREBY CAUSES INJURY IN THAT STATE.}

In International Shoe Co. v. Washington, 326 U.S. 310 (1945), this Court set aside the idea that a defendant's "presence within the territorial jurisdiction of [the] court" was a necessary prerequisite to the exercise of personal jurisdiction. Id. at 316 (citing Pennoyer v. Neff, 95 U.S. 714, 733 (1877)). Rather, "due process requires only that in order to subject a defendant to a judgment in personam, if he be not present within the territory of the forum, he have certain minimum contacts with it such that the maintenance of the suit does not offend traditional notions of fair play and substantial justice." Id.

During the 1980s, this Court articulated a twopart framework for validating a state's exercise of personal jurisdiction under the Fourteenth Amendment. First, the defendant must "purposefully establish[] 'minimum contacts' in the forum State"; second, "[o]nce it has been decided that a defendant purposefully established minimum contacts within the forum State, these contacts may be considered in light of other factors to determine whether the assertion of personal jurisdiction would comport with 'fair play and substantial justice.'" Burger King Corp. $v$. Rudzewicz, 471 U.S. 462, 474, 476 (1985) (quoting 
Int'l Shoe, 326 U.S. at 316, 320). These other factors include "the burden on the defendant, the forum State's interest in adjudicating the dispute, the plaintiff's interest in obtaining convenient and effective relief, the interstate judicial system's interest in obtaining the most efficient resolution of controversies, and the shared interest of the several States in furthering fundamental substantive social policies." Id. at 477 (citation and internal quotation marks omitted).

Petitioner challenges jurisdiction exclusively under the first prong of this framework, conceding that "[t]he sole concern is whether J. McIntyre had minimum contacts with New Jersey." Pet. Br. 30. This is no surprise. Where, as here, the injured party sues in the state where the product was delivered to the end-user and where the injury occurred, these "other factors" point strongly in favor of exercising jurisdiction. A state has a strong interest in adjudicating a dispute involving a product that was purchased and used by an in-state business and caused an in-state injury to an in-state plaintiff. See, e.g., Burger King, 471 U.S. at 473 ("A State generally has a manifest interest in providing its residents with a convenient forum for redressing injuries inflicted by out-of-state actors." (internal quotation marks omitted)). Such a state is also likely to be convenient for accessing evidence relevant to the use of the product, the accident itself, and the plaintiff's damages and injuries.

Turning to the minimum-contacts argument that is the sole basis for Petitioner's jurisdictional 
challenge, this Court has consistently held that a manufacturer establishes minimum contacts with a state when it seeks to serve the market in that state and its product thereby causes injury in that state. Indeed, this principle has never been questioned by even a single Justice in the six-and-a-half decades since International Shoe. In World-Wide Volkswagen Corp. v. Woodson, 444 U.S. 286 (1980), for example, this Court wrote:

"[I]f the sale of a product of a manufacturer or distributor ... arises from the efforts of the manufacturer or distributor to serve directly or indirectly, the market for its product in other States, it is not unreasonable to subject it to suit in one of those States if its allegedly defective merchandise has there been the source of injury to its owner or to others."

Id. at $297 .^{2}$

${ }^{2}$ Jurisdiction was denied in World-Wide Volkswagen because the defendants had not sought to serve, either directly or indirectly, the market for their product in the forum state of Oklahoma. The defendants were a New York car dealership that served solely the New York market and a New York distributor who served the New York market and surrounding areas in two other states. Id. at 288-89. The automobile involved in the accident had been sold to a local New York customer, but it found its way to Oklahoma via the customer's "unilateral activity," $i d$. at 298, not by any effort on the part of the defendants to reach the Oklahoma market with their products. See also Asahi, 480 U.S. at 109 (O'Connor, J.) (noting that World-Wide Volkswagen "rejected the assertion that a consumer's unilateral act of bringing the defendant's product into the forum State was

(Continued on following page) 
This Court's most recent case on this issue, Asahi Metal Industry Co. Ltd. v. Superior Court, 480 U.S. 102 (1987), yielded no majority opinion on whether the defendant in that case had established minimum contacts with the forum. Four Justices led by Justice O'Connor concluded that Asahi had not established minimum contacts with California. Id. at 112-113 (O'Connor, J.). Four Justices led by Justice Brennan concluded that Asahi had established minimum contacts with California. Id. at 121 (Brennan, J.). ${ }^{3}$

a sufficient constitutional basis for personal jurisdiction over the defendant" (emphasis in original)).

${ }^{3}$ Justice Stevens did not join either Justice O'Connor's or Justice Brennan's opinion on this issue. Id. at 121-122 (Stevens, J.). Despite the split on whether Asahi had established minimum contacts with California, this Court found jurisdiction to be improper under the second prong of the test discussed above, due to unique aspects of that case that made jurisdiction inconsistent with "traditional notions of fair play and substantial justice" regardless of whether Asahi had established minimum contacts with the forum. Id. at 113 (quoting Int'l Shoe, 326 U.S. at 316). Petitioner does not and cannot present a similar argument here. See Pet. Br. 30 ("The sole concern is whether J. McIntyre had minimum contacts with New Jersey."). As discussed above, the "other factors" relevant to this second prong point strongly in favor of jurisdiction where, as here, the injured party sues in the state where the product was delivered to the end-user and where the injury occurred. Asahi was an unusual case in this regard. Although the accident that gave rise to the lawsuit occurred in California, the claims by the injured California plaintiff were settled. Asahi, 480 U.S. at 105-06. Thus the lawsuit that reached this Court concerned only an indemnification claim by a Taiwanese company (Cheng Shin) against a Japanese company (Asahi). This Court reasoned that this odd posture undermined the reasonableness of jurisdiction. See

(Continued on following page) 
Some courts have read Justice Brennan and Justice O'Connor as endorsing fundamentally different standards for assessing minimum contacts. See, e.g., Vermeulen v. Renault, U.S.A., Inc., 985 F.2d 1534, 1547-49 \& n.17 (11th Cir. 1993) (distinguishing between a "stream of commerce" analysis and a "stream of commerce plus" analysis). This characterization, however, overlooks their shared recognition of the basic principle that a manufacturer establishes minimum contacts with the forum when it seeks to serve - directly or indirectly - the market in the forum state and its product thereby causes injury in that state. Both Justice O'Connor and Justice Brennan explicitly embraced the passage from World-Wide Volkswagen quoted above:

"[I]f the sale of a product of a manufacturer or distributor ... arises from the efforts of the manufacturer or distributor to serve, directly or indirectly, the market for its product in other States, it is not unreasonable to subject it to suit in one of those States if its allegedly defective merchandise has there

\footnotetext{
Asahi, 480 U.S. at 114 ("[T]he interests of the plaintiff and the forum in California's assertion of jurisdiction over Asahi are slight. All that remains is a claim for indemnification asserted by Cheng Shin, a Taiwanese corporation, against Asahi.... Because the plaintiff is not a California resident, California's legitimate interests in the dispute have considerably diminished.”).
} 
been the source of injury to its owner or to others."

Asahi, 480 U.S. at 110 (O'Connor, J.) (quoting WorldWide Volkswagen, 444 U.S. at 297); id. at 119 (Brennan, J.) (same). While Justice O'Connor stated that "placement of a product into the stream of commerce, without more, is not an act of the defendant purposefully directed toward the forum State," she recognized unequivocally that jurisdiction is permissible if the defendant's conduct "indicate[s] an intent or purpose to serve the market in the forum State." Id. at 112 (O’Connor, J.) (emphasis added).

\section{A MANUFACTURER THAT PURPOSE- FULLY ENDEAVORS TO SERVE THE U.S. MARKET AS A WHOLE NECESSARILY SERVES, AT LEAST INDIRECTLY, THE MARKET FOR EACH U.S. STATE.}

As explained above, this Court has consistently recognized that a manufacturer establishes minimum contacts with a state when it seeks to serve the market in that state and its product thereby causes injury in that state. The plaintiff in this case alleges that he suffered an injury in the forum state that was caused by a product purchased by a customer in the forum state. A New Jersey business purchased the shear machine from Petitioner's exclusive U.S. distributor, and the machine injured that business's 
employee in New Jersey. ${ }^{4}$ Thus the only potential obstacle to validating jurisdiction is whether Petitioner took purposeful steps to serve - directly or indirectly - the New Jersey market. For the reasons that follow, the answer must be yes.

Although amici will not reiterate here the full factual record (which is set forth in detail in the Respondents' brief and in the opinions below), it is clear that Petitioner purposefully sought to serve and profit from the U.S. market for the large metal shearing machines that it manufactured in Great Britain. Petitioner entered into an agreement with Ohiobased McIntyre America that designated McIntyre America the exclusive distributor for Petitioner's products in the territory of the United States. McIntyre America was not an end-user of Petitioner's machines, but was a conduit for selling Petitioner's already-finished machines to customers in the United States. ${ }^{5}$ Petitioner's own literature for the shear

${ }^{4}$ A different analysis might be necessary if the injury was either suffered outside the forum or caused by a product that was ultimately sold to a customer outside the forum. In that situation, it could be argued that the claim does not "aris[e] out of or relate[] to" the defendant's contacts with the forum. $C f$. Helicopteros Nacionales de Colombia, S.A. v. Hall, 466 U.S. 408 (1984). The companion case for which this Court has also granted certiorari, Goodyear Dunlop Tires Operations, S.A. v. Brown (No. 10-76), may implicate this latter scenario. This brief takes no position on the propriety of jurisdiction in the Goodyear case.

${ }^{5}$ The record reveals that McIntyre America was "America's link" to Petitioner's products. JA 28a. Under its arrangement (Continued on following page) 
machine at issue touts that it conforms to American safety standards.

By taking these purposeful steps to reach the entire U.S. market, Petitioner necessarily sought to serve, at least indirectly, the New Jersey market as well. Sales of Petitioner's shear machines to customers in the particular states that comprise the United States were surely a "contemplated future consequence[]" of Petitioner's purposeful conduct. Burger King, 471 U.S. at 479. Given Petitioner's efforts to reach and profit from the U.S. market as a whole, sales within that market cannot be deemed "random, fortuitous, or attenuated." Id. at 480 (citations omitted).

with Petitioner, Petitioner shipped new machines to McIntyre America with the expectation that they would be sold in the United States, but those machines would remain Petitioner's property until they were paid for in full. JA 134a. As Petitioner's own officers described it, the arrangement was designed to "sell [Petitioner's] products in the United States - and get paid!" JA 134a (email from Petitioner's officer to McIntyre America stating: "All we wish to do is sell our products in the States and get paid! If this isn't possible then the only other option open to us is for us to split up in an amiable fashion as quickly as we can. I note that you still have new machines in stock, which you are presently unable to sell. Please note that those machines are our property until they have been paid for in full."). To that end, Petitioner's own officials attended dozens of trade shows in the United States in an effort to promote the sales of its machines to U.S. customers, JA 114a-117a, and McIntyre America "structured [its] advertising and sales efforts in accordance with [Petitioner's] direction and guidance whenever possible." JA 124a. 
To reject jurisdiction in this case would be to embrace the strange principle that the whole (the United States) is somehow less than the sum of its parts (the individual states). Petitioner, for example, expresses concern that a defendant who purposefully seeks access to the U.S. market could be subject to jurisdiction in New Jersey even if it had not "thought about New Jersey or even knew that it exists." Pet. Br. 27. It is logically impossible, however, to serve the U.S. market generally without serving the states that comprise the United States. Even for a hypothetical defendant who aggressively seeks access to the U.S. market but is unaware that particular states "exist[]," Pet. Br. 27, there should be no surprise that jurisdiction would be proper in some court within the territory of the U.S. market from which it purposefully sought to profit.

Indeed, the conclusion that Petitioner established minimum contacts with New Jersey is supported by both sides of this Court's 4-4 split in Asahi. As explained supra Part I, both Justice Brennan and Justice O'Connor endorse the core principle that a manufacturer establishes minimum contacts with the forum when it seeks to serve - directly or indirectly the market in the forum state and its product thereby causes injury in that state. For Justice Brennan, sufficient contacts exist when a manufacturer "delivers its products into the stream of commerce with the expectation that they will be purchased by consumers in the forum State." Asahi, 480 U.S. at 119-20 (Brennan, J.). In this situation, the manufacturer 
"benefits economically from the retail sale of [its] product in the forum State, and indirectly benefits from the State's laws that regulate and facilitate commercial activity." Id. at 117. "These benefits accrue regardless of whether that participant directly conducts business in the forum State, or engages in additional conduct directed toward that State." Id. The shear machine at issue in this case reached New Jersey via a "chain of distribution," $i d$. at 120 , that led from Petitioner, to the U.S. distributor that it retained for the explicit purpose of selling its machines to U.S. customers, to the New Jersey customer who purchased the machine. That the machine involved in this case reached New Jersey is hardly due to "unpredictable currents or eddies." Id. at 117.

Justice O'Connor, admittedly, reasoned that a defendant's efforts must be more than mere "placement of a product into the stream of commerce." Asahi, 480 U.S. at 112 (O'Connor, J.). But even Justice O'Connor would find the minimum-contacts test satisfied where the defendant's conduct "indicate[s] an intent or purpose to serve the market in the forum State." Id. (emphasis added). ${ }^{6}$ When a defendant

${ }^{6}$ Such conduct may include, among other things, "designing the product for the market in the forum State, advertising in the forum State, establishing channels for providing regular advice to customers in the forum State, or marketing the product through a distributor who has agreed to serve as the sales agent in the forum State." Id. at 112. 
designs its product to comply with U.S. safety standards, designates a U.S. distributor to serve the U.S. market in its entirety, and takes further steps to facilitate sales within that undifferentiated U.S. market, it manifests an intent or purpose to serve, at least indirectly, the markets in the states that comprise the United States.

On this issue, it is worth noting lower court decisions that Justice O'Connor cited in her Asahi opinion in explaining why jurisdiction was improper on the facts of Asahi. Stating that Asahi had not "designed its product in anticipation of sales in California," Justice O'Connor compared Asahi to Rockwell International Corp. v. Costruzioni Aeronautiche Giovanni Agusta, 553 F. Supp. 328 (E.D. Pa. 1982). ${ }^{7}$ The defendant in Rockwell was SNFA, a French corporation that manufactured ball-bearing assemblies designed to be used in a particular helicopter called the A-109. SNFA sold its assemblies to its Italian subsidiary, which sold them to the Italian helicopter manufacturer (Agusta), which incorporated the bearings into its A-109 helicopters. Agusta then sold the helicopters to a U.S. distributor in Delaware that would in turn sell to consumers in the United States. Id. at 329 .

${ }^{7}$ See Asahi, 480 U.S. at 113 (O'Connor, J.) ("There is no evidence that Asahi designed its product in anticipation of sales in California. Cf. Rockwell International Corp. v. Costruzioni Aeronautiche Giovanni Agusta, 553 F. Supp. 328 (E.D. Pa. 1982).”). 
Even though SNFA played no role in distributing the helicopters themselves in the United States, jurisdiction was appropriate in Pennsylvania because SNFA had purposefully designed its bearing assemblies for use in the A-109 helicopter and was "aware that the A-109 helicopter was targeted for the executive corporate transport market in the United States and Europe." Id. at 330. "Given the distribution system, SNFA had ample reason to know and expect that its bearing, as a unique part of a larger product, would be marketed in any or all states, including the Commonwealth of Pennsylvania." Id. at 333 (emphasis in original).

The logic of Rockwell applies with even stronger force to this case. Petitioner not only knew of the distribution system that would lead its products to the U.S. market, it purposefully engaged the U.S. distributor who would serve that function. Here, as in Rockwell, the Petitioner manufactured the product with the knowledge that it would be sold in the United States; Petitioner even touted its product's compliance with U.S. safety standards. Here, as in Rockwell, it makes no difference that the Petitioner did not specifically target the individual states that comprise the United States. ${ }^{8}$

\footnotetext{
${ }^{8}$ Justice O'Connor also cited Hicks v. Kawasaki Heavy Industries, 452 F. Supp. 130 (M.D. Pa. 1978). See Asahi, 480 U.S. at 112-13 (O'Connor, J.). Unlike in Hicks, Justice O'Connor noted, Asahi did not "create, control, or employ the distribution system" that brought its product to the forum. In Hicks, on the (Continued on following page)
} 
Accordingly, Justice O'Connor's conclusion that Asahi had not established minimum contacts with California is entirely reconcilable with upholding jurisdiction in this case. Moreover, the directdistribution scenario here involves qualitatively more purposeful and direct contacts than those in Asahi. Asahi had sold its tire valves to Cheng Shin, a Taiwanese manufacturer who in turn used Asahi's valves as components for its tire tubes. Id. at 106. Cheng Shin's fully assembled tire tubes were then delivered to the United States. Id. In the Asahi scenario, the component manufacturer played no role at all in defining where the finished tire tubes that happened

other hand, a Japanese motorcycle manufacturer had established minimum contacts with Pennsylvania even though it sold its products only to its U.S. subsidiary and not to particular consumers in particular U.S. states. Hicks reasoned that "[t]he manufacturer has the minimum contacts required by due process and is doing business by means of indirect shipments of goods into the state." Id. at 134 (emphasis added). It was irrelevant, therefore, that "the product was not directly placed in the state by [the Japanese manufacturer] but rather was marketed by one whom the [manufacturer] could foresee would cause the product to enter Pennsylvania." Id. It was also not necessary to show that the Japanese manufacturer had exercised "corporate control" over its U.S. subsidiary and distributor. Id. at 134-35. As Hicks explained: "Any other result would permit a foreign corporation to market its product in this state, profit from its sale here and yet retain immunity simply by structuring its business operations so as to avoid direct activity in the Commonwealth." Id. at 134. Likewise, in the case at bar, a lack of "direct activity" in New Jersey would not foreclose jurisdiction. 
to contain Asahi's valves would be sold. Id. at 112 (O'Connor, J.) ("'Asahi] did not create, control, or employ the distribution system that brought its valves to California."). Under the logic of Justice O'Connor's opinion, one might say that such a component manufacturer acts to serve the needs of the finished-product manufacturer (in Taiwan), not the market where the finished product is ultimately purchased.

In this case, by contrast, Petitioner defined the scope of distribution by entering into a distribution arrangement with a U.S. distributor that contemplated sales of its already-finished product throughout the United States. Petitioner's own materials touted its product's purported compliance with U.S. safety standards. It would be strange indeed to say that Petitioner's U.S. distributor in Ohio was the "market" that Petitioner sought to serve. Such a distributor is purely a conduit that adds no value other than to reach the market designated by the manufacturer. Petitioner's economic rationale for enlisting McIntyre America was to give Petitioner access to the entire U.S. market. As the record confirms, Petitioner sought to "sell [its] products in the United States - and get paid!" JA 134a. ${ }^{9}$

${ }^{9}$ This comparison to Asahi is not a concession that minimum contacts are necessarily lacking when a manufacturer's product is incorporated into the finished product of another manufacturer. Four Justices concluded that Asahi had indeed established minimum contacts with California, Asahi, 480 U.S. (Continued on following page) 
To refuse jurisdiction in this case would mean that a manufacturer who deliberately seeks to access the U.S. market could evade jurisdiction in the particular U.S. state where a defective product is distributed and causes injury. Indeed, the arguments presented by Petitioner and its amici would insulate such a manufacturer from jurisdiction in any U.S. state, despite its purposeful efforts to access the entire U.S. market. ${ }^{10}$ A manufacturer should not be

at 121 (Brennan, J.). Such a component manufacturer, after all, "benefits economically from the retail sale of the final product in the forum State, and indirectly benefits from the State's laws that regulate and facilitate commercial activity. These benefits accrue regardless of whether that participant directly conducts business in the forum State, or engages in additional conduct directed toward that State." Id. at 117 (Brennan, J.). As explained above, the direct-distribution scenario presented in this case is a fortiori stronger than the facts of Asahi.

${ }^{10}$ See Chamber of Commerce Amicus Br. at 19 (arguing that its approach "may, of course, result in certain cases where a citizen of the forum state is injured in the forum state by an overseas manufacturer's product and yet not have an American forum in which to sue the manufacturer"). The briefs of Petitioner and its amici acknowledge only a single method by which Mr. Nicastro could obtain relief in a U.S. court on these facts sue the now-bankrupt distributor McIntyre America in its home state of Ohio on a substantive theory that it is liable for Petitioner's manufacturing or design defects. See PLAC Amicus Br. 23. That the Petitioner's U.S. distributor is bankrupt may reveal yet another reason why jurisdiction is more compelling in this case than on the facts of Asahi. The end-product manufacturer in Asahi incorporated Asahi's components into a new product, a tire tube, which had a market value independent of the individual components it contained. By contrast, a mere distributor particularly one whose sole job is to sell a single manufacturer's products - may not have the sort of robust, value-adding

(Continued on following page) 
able to seek out U.S. customers for its products but then evade accountability in U.S. courts when those products cause injuries within the United States. For the reasons explained above, the Fourteenth Amendment does not incapacitate American courts from deciding claims arising from a foreign manufacturer's purposeful conduct directed at the U.S. market.

\section{ALLOWING JURISDICTION WOULD NOT CONFLATE "NATIONAL CONTACTS" WITH "STATE CONTACTS"}

Contrary to the arguments of Petitioner's amici, to allow jurisdiction in this case would not be to exercise jurisdiction based on "national contacts"

business that would generate the assets needed to pay judgments when those products cause injuries.

In any event, none of the Petitioner-side briefs concede that Ohio (or any other U.S. court) could obtain jurisdiction over Petitioner, despite Petitioner's purposeful efforts to access the U.S. market for its products. Even if Petitioner itself were subject to jurisdiction in Ohio, that would not undermine the propriety of jurisdiction in New Jersey - the state to which the product was ultimately sold to an end user, and in which the product caused injury. Petitioner entered into an arrangement with a U.S. distributor that sought to access the entire U.S. market. If any of the relevant contacts in this case are "fortuitous," it is not that Petitioner's shear machine ended up in New Jersey, but rather that its national distributor, on whom Petitioner bestowed exclusive rights to distribute its machines throughout the United States, happened to be based in Ohio rather than any of the other U.S. states. 
rather than on contacts with the forum state. Jurisdiction does not hinge on a principle that any contacts anywhere in the United States automatically count as contacts with every state. A manufacturer who arranges with a distributor to sell its goods only in a single state's market does not necessarily become amenable to jurisdiction throughout the United States. ${ }^{11}$

A defendant like Petitioner, by contrast, purposefully acts to serve the entire U.S. market. By doing so, Petitioner is serving - at least indirectly - the market in each of the fifty states. Such a defendant's purposeful efforts to access customers in the states that comprise the United States constitute minimum contacts with those states. They therefore justify jurisdiction when the defendant's product is ultimately sold to a customer in the forum state and causes injury in that state. Under a national contacts

${ }^{11}$ Relatedly, businesses who serve their own local markets would not automatically become subject to jurisdiction nationwide. Thus, allowing jurisdiction in this case would not frustrate the concerns expressed in World-Wide Volkswagen that "a local California tire retailer could be forced to defend in Pennsylvania when a blowout occurs there, a Wisconsin seller of a defective automobile jack could be haled before a distant court for damage caused in New Jersey, or a Florida soft-drink concessionaire could be summoned to Alaska to account for injuries happening there." 444 U.S. at 296 (citing Erlanger Mills, Inc. v. Cohoes Fibre Mills, Inc., 239 F.2d 502, 507 (4th Cir. 1956); Reilly v. Phil Tolkan Pontiac, Inc., 372 F. Supp. 1205 (D.N.J. 1974); Uppgren v. Executive Aviation Services, Inc., 304 F. Supp. 165, 170-171 (D. Minn. 1969)). 
approach, on the other hand, Mr. Nicastro could sue Petitioner in all fifty states.

Accordingly, the insistence by Petitioner's amici that jurisdiction is unconstitutional absent congressional legislation is misguided. One amicus brief alludes to Justice O'Connor's suggestion in Asahi that "Congress could, consistent with the Due Process Clause of the Fifth Amendment, authorize federal court personal jurisdiction over alien defendants based on the aggregate of national contacts, rather than on the contacts between the defendant and the State in which the federal court sits." Asahi, 480 U.S.

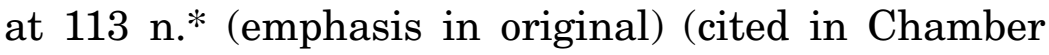
of Commerce Amicus Br. 19). For all the reasons discussed above, however, established Fourteenth Amendment principles confirm that jurisdiction is appropriate in New Jersey, even under Justice O'Connor's own reasoning in Asahi.

The discussion by Petitioner's Amici of Federal Rule of Civil Procedure 4(k)(2), see Chamber of Commerce Amicus Br. 20-21; PLAC Amicus Br. 27-28, is similarly misplaced. It is not suggested that Rule $4(\mathrm{k})(2)$ would allow a U.S. federal court to exercise jurisdiction over this case; Rule 4(k)(2) applies only to claims that "arise[] under federal law." Fed. R. Civ. P. $4(\mathrm{k})(2)$. Rather, amici invoke Rule $4(\mathrm{k})(2)$ in an attempt to buttress their mistaken view that Petitioner has not made sufficient contacts with New Jersey (or any U.S. state) to satisfy the Fourteenth Amendment. 
It is correct that Rule $4(\mathrm{k})(2)$ allows a federal court to exercise jurisdiction in federal-question cases where a state court could not do so, ${ }^{12}$ and that the constitutionality of a federal court's assertion of jurisdiction under Rule 4(k)(2) would be governed by the Fifth Amendment's, rather than the Fourteenth Amendment's, Due Process Clause. ${ }^{13}$ But these principles say nothing at all about when state court jurisdiction is permissible under the Fourteenth Amendment. The Omni Capital decision that precipitated the enactment of Rule 4(k)(2) is instructive. See Fed. R. Civ. P. 4, advisory committee notes (1993 amendment, subdivision (k)) (citing Omni Capital Intern., Ltd. v. Rudolf Wolff \& Co., 484 U.S. 97, 111 (1987)). This Court in Omni Capital did not hold or even intimate that the Fourteenth Amendment

${ }^{12}$ Before Rule 4(k)(2), a federal district court's assertion of personal jurisdiction was generally limited to that which a state court in that same state could exercise. See Fed. R. Civ. P. $4(\mathrm{k})(1)(\mathrm{A})$. This could create a "gap" in the enforcement of federal law if the relevant state court could not exercise jurisdiction. Omni Capital Intern., Ltd. v. Rudolf Wolff \& Co., 484 U.S. 97 (1987) (rejecting argument that this Court should, via decisional law, "fashion[] a remedy to fill a gap in the Federal Rules of Civil Procedure").

${ }^{13}$ See Fed. R. Civ. P. 4, advisory committee notes (1993 Amendment) ("There remain constitutional limitations on the exercise of territorial jurisdiction by federal courts over persons outside the United States. These restrictions arise from the Fifth Amendment rather than from the Fourteenth Amendment."). 
forbade Louisiana from exercising jurisdiction over the defendant. Rather, Louisiana's long-arm statute had voluntarily restricted the scope of its state courts' jurisdiction. Omni Capital, 484 U.S. at 108. While Rule 4(k)(2)'s Advisory Committee Notes recognize that the rule would also allow a federal court to exercise federal-question jurisdiction in a case where a defendant has "insufficient contact with any single state to ... meet the requirements of the Fourteenth Amendment limitation on state court territorial jurisdiction," Fed. R. Civ. P. 4, advisory committee notes (1993 amendment, subdivision (k)), that does not prejudge the question of whether the Fourteenth Amendment is or is not satisfied in any given situation.

In this case, jurisdiction is justified based on Petitioner's purposeful efforts to serve, at least indirectly, the New Jersey market. Accordingly, upholding jurisdiction is entirely consistent with the premise that the Fourteenth Amendment's Due Process Clause requires minimum contacts with the forum State. ${ }^{14}$

${ }^{14}$ This Court has stated that the constitutional limitations on personal jurisdiction are "ultimately a function of the individual liberty interest preserved by the Due Process Clause," rather than "federalism concerns" that "operate[] as an independent restriction on the sovereign power of [state] court[s]." Insurance Corp. of Ireland, Ltd. v. Compagnie des Bauxites de Guinee, 456 U.S. 694, 702-03 n.10 (1982); accord Burger King, 471 U.S. at 472 n.13 ("Although [the Due Process Clause] operates to restrict state power, it must be seen as ultimately a function of the individual liberty interest preserved by the Due

(Continued on following page) 


\title{
IV. ALLOWING JURISDICTION WILL NOT INVITE “A SUBJECTIVE JUDGE-BY-JUDGE ASSESSMENT OF WHAT IS FAIR AND JUST" OR DEPRIVE DEFENDANTS OF "FAIR WARNING" THAT THEIR CONDUCT WILL SUBJECT THEM TO JURISDICTION.
}

\author{
Quoting Justice Scalia's opinion in Burnham $v$. \\ Superior Court, 495 U.S. 604, 623 (1991), Petitioner
}

Process Clause rather than as a function of federalism concerns." (quotations omitted)). This individual-liberty rationale has led some to question whether minimum contacts with the forum state should remain a "constitutional touchstone" for Due Process purposes, Burger King, 471 U.S. at 474, rather than more traditional Due Process concerns. See Martin H. Redish, Due Process, Federalism, and Personal Jurisdiction: A Theoretical Evaluation, 75 Nw. U. L. REv. 1112, 1115 (1981) (arguing that constitutional limits on personal jurisdiction should "reflect the traditional due process concern for preventing injustice to the individual" rather than "prelitigation contacts between the defendant and the forum"); see also Patrick J. Borchers, The Death of the Constitutional Law of Personal Jurisdiction: From Pennoyer to Burnham and Back Again, 24 U.C. Davis L. Rev. 19 (1990); A. Benjamin Spencer, Jurisdiction to Adjudicate: A Revised Analysis, 73 U. CHI. L. REv. 617 (2006). Some have also questioned whether a foreign defendant must establish minimum contacts with any particular state (rather than with the United States as a whole), noting that "for international law purposes it is inconsequential how ... power is allocated among political subdivisions within [a] country." Graham C. Lilly, Jurisdiction over Domestic and Alien Defendants, 69 VA. L. REv. 85, 126-127 \& n.155 (1983). The case at bar, however, does not require this Court to revisit the premise that minimum contacts with the forum state are required, because Petitioner has indeed established minimum contacts with New Jersey as explained above. 
asserts that allowing jurisdiction in this case will lead to a "subjective judge-by-judge assessment of what is fair and just." 15 To the contrary, Justice Scalia's Burnham opinion confirms that such subjectivity can be avoided just as readily by a rule that permits jurisdiction in a particular scenario as by one that forbids jurisdiction in a particular scenario.

In Burnham, Justice Scalia's plurality opinion adopted a rule that service of process on a defendant within the forum state was per se constitutional. 495 U.S. at 619 (Scalia, J.) ("The short of the matter is that jurisdiction based on physical presence alone constitutes due process."). Justice Scalia argued that such a categorical approach would avoid "uncertainty and litigation over the preliminary issue of the forum's competence," and therefore was preferable to a "totality of the circumstances" test that would make the propriety of such transient jurisdiction vary on a case-by-case basis. Id. at 626 ; id. at 623 (criticizing an approach that would invite a "subjective assessment of what is fair and just").

Likewise, this Court would minimize potential uncertainty and subjectivity by articulating a clear rule that a manufacturer establishes minimum contacts with the forum state when it purposefully endeavors to access the U.S. market generally and its product is thereby distributed to and causes injury in

${ }^{15}$ Pet. Br. 41, 48 (quoting Burnham, 495 U.S. at 623 (Scalia, J.)). 
the forum state. As discussed supra Parts I \& II, this principle is well-supported by this Court's case law. Although this principle will not mechanically determine the propriety of jurisdiction for every set of facts that courts might be faced with going forward, it provides a predictable answer to a fairly common scenario. $^{16}$

Petitioner's argument that allowing jurisdiction would deny defendants "fair warning" that their conduct will subject them to jurisdiction is similarly unavailing. ${ }^{17}$ There is, admittedly, a potentially

${ }^{16}$ Jurisdictional rules may always remain somewhat murky at the margins. This Court's recent decision in Hertz Corp. $v$. Friend, 130 S. Ct. 1181 (2010), unanimously embraced the socalled "nerve center" test for determining a corporation's principal place of business for purposes of federal diversity jurisdiction, $i d$. at 1186, noting that the "administrative simplicity" of this approach would "promote greater predictability." Id. at 1193. But this Court candidly recognized that "there may be no perfect test," and that "there will be hard cases" even under the "nerve center" approach. Id. at 1194; see also Burnham, 495 U.S. at 626 (Scalia, J.) (noting the "evils" of "uncertainty and litigation over the preliminary issue of the forum's competence" but recognizing: "It may be that those evils . . . must be accepted at the margins" (citing Asahi)).

${ }^{17}$ See Pet. Br. 18 (quoting Burger King, 471 U.S. at 472). With respect to subjectivity and fair warning, Petitioner's critique of Justice Brennan's Asahi opinion as compared to Justice O'Connor's Asahi opinion is somewhat puzzling. Petitioner describes Justice Brennan's emphasis on whether the defendant was "aware" that its goods would be sold in the forum as a troubling inquiry into a defendant's "mere state of mind." Pet. Br. 44. Yet Petitioner embraces Justice O'Connor's opinion, which would inquire whether the defendant acted with "an (Continued on following page) 
circular quality to the idea that defendants must "have fair warning that a particular activity may subject them to the jurisdiction of a foreign sovereign," Burger King, 471 U.S. at 472 (citations omitted), and to the related idea that jurisdiction must be "foreseeable" in the sense that defendants "should reasonably anticipate being haled into court" in the forum state. World-Wide Volkswagen, 444 U.S. at 296297. It is, after all, the jurisdictional principles themselves that would make jurisdiction foreseeable or would otherwise provide fair warning of what activity will subject a defendant to jurisdiction. ${ }^{18}$ If applied unthinkingly, these concepts could yield problematic results at both ends of the jurisdictional spectrum. At one extreme, they could legitimate a state's plainly exorbitant exercise of jurisdiction so long as the

intent or purpose to serve the market in the forum State," $i d$. at 112 (O'Connor, J.), even though that standard also seems to implicate a defendant's state of mind. In any event, as explained supra Parts I \& II, Justice O'Connor's reasoning in Asahi is entirely consistent with finding jurisdiction in this case. To be clear, Justice Brennan's Asahi opinion did not require that the defendant was aware that any specific product was in fact purchased by a customer in the forum state; he reasoned that minimum contacts were established when a manufacturer "delivers its products into the stream of commerce with the expectation that they will be purchased by consumers in the forum State." Asahi, 480 U.S. at 119-20 (Brennan, J.) (emphasis in original) (quoting World-Wide Volkswagen, 444 U.S. at 298).

${ }^{18}$ See Redish, supra note 14, at 1134 ("[A] potential defendant can only have such an expectation because the law so provides."). 
state's law was clear enough to give defendants notice of its desired jurisdictional scope. At the other extreme, these notions could foreclose any evolution of jurisdictional principles; International Shoe's recognition that an absent defendant can be subject to jurisdiction if it establishes minimum contacts with the forum state would have foundered on the argument that defendants lacked "fair warning" that Pennoyer's requirement of in-forum service of process would be relaxed. ${ }^{19}$

Whatever independent legwork "fair warning" or "foreseeability" perform in this Court's jurisdictional analysis, those requirements are more than satisfied here. It should come as no surprise that a manufacturer who purposefully seeks access to the U.S. market would be subject to jurisdiction within the territory of that market for claims that arise from the sale of its products there. As explained above, such jurisdiction is supported by this Court's longstanding, unquestioned basic principles, see supra Part I, by both sides of the split between Justices Brennan and O'Connor in Asahi, and even by lower court cases cited by Justice O'Connor in articulating

${ }^{19}$ The requirements of "foreseeability" and "fair warning" are surely not designed to create a form of jurisdictional "qualified immunity" that would prevent jurisdiction unless the constitutionality of such jurisdiction was "clearly established." Cf., e.g., Anderson v. Creighton, 483 U.S. 635 (1987) (describing government officials' qualified immunity from civil damage awards unless their conduct runs afoul of "clearly established" constitutional principles). 
her ostensibly narrower view of the minimumcontacts test. See supra Part II. Jurisdiction is also supported by numerous lower court decisions since Asahi, which have embraced the idea that when a defendant endeavors to serve a broad market such as the U.S., it purposefully acts to serve the smaller markets that comprise it. ${ }^{20}$ Petitioner attempts to characterize many of these decisions as examples of "abuse by lower courts." Pet. Br. 45. In fact, these decisions confirm that jurisdiction is proper under a straightforward application of this Court's principles.

\section{THE NEW JERSEY SUPREME COURT'S CONCLUSION THAT PERSONAL JURIS- DICTION EXISTS IS CONSISTENT WITH THIS COURT'S CASE LAW AND SHOULD BE AFFIRMED.}

Fixating on a few snippets in the majority opinion below, Petitioner and its amici argue that the Supreme Court of New Jersey drastically misapplied this Court's jurisdictional doctrine. In particular, they argue that the majority opinion would permit jurisdiction even without the defendant establishing

${ }^{20}$ See, e.g., Kernan v. Kurz-Hastings, Inc., 175 F.3d 236, 243-44 (2d Cir. 1999); Barone v. Rich Bros. Interstate Display Fireworks Co., 25 F.3d 610, 613-15 (8th Cir. 1994); Tobin v. Astra Pharmaceutical Products, Inc., 993 F.2d 528 (6th Cir. 1993); A. Uberti \& C. v. Leonardo, 892 P.2d 1354, 1360-64 (Ariz. 1995); Wright v. American Home Products Corp., 768 A.2d 518, 531-36 (Del. Super. 2000). 
"minimum contacts" with the forum. This critique mistakes semantics for substance.

Admittedly, the New Jersey Supreme Court's opinion refers to a "stream of commerce" theory of jurisdiction that is distinct from a "minimum contacts" theory of jurisdiction. ${ }^{21}$ To parallel more precisely this Court's case law, the court should perhaps have written that one situation in which a manufacturer establishes "minimum contacts" with the forum is when, among other things, its products reach the forum via the "stream of commerce." So stated, there is nothing at all controversial about the lower court's reasoning.

Ultimately, of course, it is up to this Court to decide the legal issues presented by this case. As described above, jurisdiction is appropriate under this Court's established principles without regard to the particular reasoning employed by the New Jersey Supreme Court. ${ }^{22}$ That said, the New Jersey Supreme

${ }^{21}$ See Pet. App. 14a ("We do not find that J. McIntyre had a presence or minimum contacts in this State - in any jurisprudential sense - that would justify a New Jersey court to exercise jurisdiction in this case. Plaintiff's claim that J. McIntyre may be sued in this State must sink or swim with the stream-ofcommerce theory of jurisdiction."); Id. 42a (viewing "minimum contacts" as a "jurisdictional doctrine" that applies "in contract and other types of cases" while the "stream-of-commerce doctrine" is "particularly suitable in product-liability actions.").

${ }^{22}$ See, e.g., Merrell Dow Pharmaceuticals Inc. v. Thompson, 478 U.S. 804, 817 \& n.15 (1986) (affirming judgment of the (Continued on following page) 
Court's decision is most certainly not a "limitless assertion of worldwide jurisdiction ... without even a by-your-leave to this Court's jurisprudence." Pet. Br. 28. The New Jersey Supreme Court carefully explained why jurisdiction is consistent with both Justice Brennan's and Justice O'Connor's Asahi opinions on the minimum-contacts issue. ${ }^{23}$ Although the opinion occasionally employs somewhat provocative language, Pet. App. 35a (noting a "radical transformation of the international economy" and a need to "discard outmoded constructs of jurisdiction in productliability cases"), it does not ultimately "discard" anything. Its reasoning is fully consistent with the basic principle that jurisdiction is proper over a manufacturer who seeks to serve - directly or indirectly - the market in the forum state and its product thereby causes injury there. Pet. App. 3a ("Due process permits this State to provide a judicial forum for its citizens who are injured by dangerous and defective products placed in the stream of commerce by a foreign manufacturer that has targeted a geographical market that includes New Jersey.").

Court of Appeals even if certain aspects of its reasoning were erroneous).

${ }^{23}$ See, e.g., Pet. App. 32a ("[T] $]$ he additional conduct required by Justice O'Connor under her stream-of-commerce approach would be the targeting of the national market."); $i d$. at 32a-33a (“E]ven under Justice O'Connor's approach, arguably, a manufacturer would be amenable to jurisdiction in every state that is part of its national distribution scheme."). 


\section{CONCLUSION}

This Court should affirm the decision below.

Respectfully submitted,

ADAM StEINMAN

SETON HALl UNIVERSITY

SCHOOL OF LAW

One Newark Center

Newark, NJ 07102

(973) 642-8882

December 20, 2010
JUSTIN T. GREEN

Counsel of Record

JAMES P. KREINDLER

ANTHONY TARRICONE

KREINDLER \& KREINDLER LLP

750 Third Avenue

New York, NY 10017

(212) 973-3403

JGreen@Kreindler.com

Attorneys for Amici Curiae 


\section{APPENDIX}

Amici Law Professors* include:

Ronald A. Brand, Professor of Law, University of Pittsburgh School of Law

Stephen B. Burbank, David Berger Professor for the Administration of Justice, University of Pennsylvania Law School

Paul D. Carrington, Professor of Law, Duke University School of Law

Robin Effron, Assistant Professor of Law, Brooklyn Law School

Jonathan M. Gutoff, Professor of Law, Roger Williams University School of Law

Diane S. Kaplan, Associate Professor, The John Marshall Law School

Denis F. McLaughlin, Professor of Law, Seton Hall University School of Law

Arthur R. Miller, University Professor, New York University School of Law

Lumen N. Mulligan, Professor of Law, University of Kansas School of Law

* Institutional affiliations are provided for identification purposes only. 
Alexander A. Reinert, Associate Professor of Law, Benjamin N. Cardozo School of Law

Elizabeth M. Schneider, Rose L. Hoffer, Professor of Law, Brooklyn Law School

Suzanna Sherry, Herman O. Loewenstein, Professor of Law, Vanderbilt University Law School

Adam N. Steinman, Professor of Law, Seton Hall University School of Law

Louise Ellen Teitz, Professor of Law, Roger Williams University School of Law

Elizabeth G. Thornburg, Professor of Law, Southern Methodist University, Dedman School of Law

Beth Van Schaack, Associate Professor of Law, Santa Clara University School of Law

Howard M. Wasserman, Associate Professor of Law, Florida International University 